\title{
3. CONSTITUTIONAL LAW AND PANDEMICS: RESPONSIBILITY FOR SOCIAL JUSTICE AND PUBLIC HEALTH NEED(S)
}

Luís Meneses do VAle

\section{Introduction}

After being exposed to the values highlighted by the specifically bioethical prospection of the pandemic, but also to human rights (in whose discourse many of today's most pressing axiological problems of political, legal and moral nature tend to converge and intersect), it now seems proper lay eyes on the constitutional normativity responsible for assuming and reflecting those references - in a critical, constitutive and fundamental-regulatory manner - on (but also from...) the global social project by which political communities self-transcend themselves, according to the specific intentionality of that quest for a certain nomos - of, by and for - the common.

Now, as the present investigation directly questions the value and service capacity displayed and promised by law and politics in responding to the challenge posed by the current pandemic and the strong likelihood of similar emergencies in the near future, it is necessary to assert, right at the head, the place and fundamental role of constitutions in our common responsibility for justice - social, legal, public health, and health care justice: both in the quality of Grundnorm of the legally positive order, as in that of a broader cultural project of ordering and socio-political coexistence.

If one is not mistaken, a thorough legal analysis of the state (and regime) of necessity, dictated by the pandemic, would seriously risk diverting us from the main purpose of the research: less aimed at the self-reflection and self-regulation of the law and the constitution, 
whenever disturbed by emergencies of the kind, than pointed to a critical reflection of the social functions by which they try to prevent, precate and combat them. Indeed, the secondary warrants of the system's self-subsistence constitute only part of the legal and constitutional response demanded by the circumstances, which now should yield to its primary function and material meaning in the relationship with society. Nothing that would blunt the relationship with secondary, tertiary (or even quaternary) norms, especially if densified by a phenomenological understanding of both law and constitutional normativity (as a principle of 'structure-action') modus essendi: vg., in what concerns the sociological-material moment of its sources, the reality within the system, the efficacy and effectiveness on which the respective validity depends, and above all, the specific rationality and method of its practice of realization. In fact, also indirectly - as basic or supreme law, law of laws and political source of sources, occupying the apex of the normative pyramid - it ends up being challenged in the above-mentioned task of fundamental and structuring normative-material conformation of society (with all its plurality) interests, powers and values, and the societal practices, institutions and subsystems that they engender and sustain).

Omitting explanations otherwise due, but impertinent here, it is worth saying that constitutionality is intended, in this regard, as an almost ecological or eco-systemic dimension of our social dwelling in the world, as a sense of value underlying the design, architecture and dynamics of fair institutions - mediating between good and right through which, we actively seek and cultivate, in a context of plurality, the possibilities of the common; which amounts to say that through this elusive justice they aim at peace, seek the stabilizing self-correction of the basic social structure or aspire to co-move us to the promotion of the democratic and normative sociality indispensable to social integration. Hence, in spite of the previously protested scruples, it is legitimate to wonder whether, and to what extent, such nomos will be able to avoid the understandable diatribes and warnings against the temptations of social technology, of bio-political inspiration, whose techniques of governmentality and disciplinarity, the current emergency, the state of exception and the right of necessity, far from disturbing or surprising, only seem to intensify ${ }^{36}$.

36 Günther Frankenberg, Staatstechnik: Perspektiven aufRechtsstaat und Ausnahmezustand, Berlin:SuhrkampVerlag, 2010. Regarding the current pandemic-Ming-Sung 
Thus, along the following pages (I), the discourse will proceed from Ethos and Nomos, and dialectically between both, with respect to responsibility and to the reciprocal correlation between justice and health, as intentionally sanctioned by constitutional law; (II) this constitutionality, socially responsible for justice and health, will then be confronted with the limits and limitations imposed and revealed by the pandemic ananké and the tragically dilemmatic fracture between salus populi and suprema lex it makes us suffer, while offering a pretext to illuminate the theoretical and dogmatic (international and national) frameworks relevant for the matter. In this light, a chronic summary of the Portuguese response to the crisis will be sketched, mentioning its protagonists, main chapters, crucial episodes and recurring issues. To conclude (IV), very modestly, some lessons about the past and the present and, perhaps, some suggestions for the future will be drawn, animated by the constitutional synthesis of responsibility and hope (P. Häberle).

One last set of explanations should be put forward, regarding our starting point and the false evidence with which it can easily betray us. From the outset, and in the immediate follow-up to the above, the very cautious expectation in relation to the list of lessons possibly collected at the end of this journey, arises not only from historical and philosophical prudence concerning the vaunted magistracy of the past, but also from a concrete doubt about the nature of the experience provided by the difficult period we are going through; namely, with regard to the value of proof and trial that has been hastily signed to him, as an alleged moment of truth, plenty of moralizing or propaedeutic (if not therapeutic) punishment and sacrifice. After all, does it not reveal himself, also (or above all ...) liable to manipulation and diffusion of falsehoods, to illusory imagery, to perceptive deceptions and distortions and even to perverse sublimations segregated by our individual and colective unconscious? It seems far from safe, in any case, to believe it could emerge an unmistakable factor of sharpness (instead of adumbration), in terms of our self-representation and self-determination as beings-there, in-the-world and with-others.

Kuo, "From Institutional Sovereignty to Constitutional Mindset: Rethinking the Domestication of the State of Exception in the Age of Normalization", in Richard Albert/Yaniv Roznai (Eds.), Constitutionalism under Extreme Conditions: Law, Emergency, Exception, Springer, 2020, pp. 21-39; and Pedro A. Villarreal, "Public Health Emergencies and Constitutionalism Before COVID-19: Between the National and the International", Ibidem, pp. 217-238. 
These ambiguities are prolonged, etymologically, in the conceptual oscillation between exception, emergency and necessity, even if we alleviate such terms from their heavy historical and legal-dogmatic burdens: (i) the first exposes the insufficiencies of the logical reference to the rule, suggesting the liberating potential of escape, while admitting the negative connotation of expulsion or extraction of a set [put shortly: leaving from norm-ality or norm-ativity - and in what sense (emancipation, exclusion or abandonment)?]; (ii) the aletic category, translated by the second, undermining the conditions of empirical or transcendental freedom and the deontic sollen built on them, opens the never totally sutured wound of all monistic (or, if less, dialectical) normativizations of social needs; (iii) the third one seemingly dilutes itself in the generic flow of contingent events or in the long-term process of vital emergency (from phylogenesis, ontogenesis and noogenesis) and the cultural patterns generated by social complexification .

Finally, between light and shadow, rule and exception, what is necessary and what is due, it would have to be clarified, if there were time, the specific difference of the times we're going through, therefore analogically comparing the old with the new, while reflexively reconstructing the tertium implied (FJ Bronze) in that exercise of historical rationalization, crucial in order to gain a clear understanding of the peculiar temporality of constitutions as ongoing collective responses - from, to, by and before something and someone.

Refusing any uncritical fascination with the new, as well as the relativism of a nibil novum sub sole attitude (which absorbs all the surprise in indifference), one must consider (i) the accumulated knowledge generated by the general intellect in matters of pandemics, (ii) the historical and reflective patrimony of constitutional law, in relation to situations of emergency, necessity or exception - without thereby undermining the kairós for social critique and the subsequent invention/discovery of transformative criteria of organization and action, provided by the current crisis.

As for the first (but also contributing to the substantiation of the second), suffice is to recall the succession of crises that we have been facing for some time - from the eruption of new forms of terrorism (after 9/11), going through the economic and financial debacle (of 2007), till the multiplication of natural disasters (typhoons, fires, floods) and the accumulation of pandemic episodes (SARS, Avian Flu, Ebola, Zika) 
and the acuity they confer to the national and international preparation and response agenda ${ }^{37}$.

With regard to the second, it would be foremost advisable not to neglect the changes prompted by relatively similar phenomena in the past ${ }^{38}$, and the way many aspirations and desires born from those events or fed by the slow and pervasive accretion of injustices - suddenly uncovered in outbreaks of indignation - act as pressing redeemable promises.

\section{Responsibility and Constitutionality: between Ethos and Nomos}

\section{Responsibility}

Despite its seminal role in the universe of our normative references, responsibility can be said to have emerged relatively late in the philo-

37 It should be noted that the WHO dedicated its 2007 annual report to health security. In addition, it was proposed to devote 2019 to the theme of preparation and response, within the framework of a five-year plan initiated in 2018 - v. WHO, The World Health Report 2007: Global Public Health Security in the 21st Century, WHO, Geneva, 2007 and the Director General's Report, Public health emergencies: preparedness and response, Annual report on the implementation of the International Health Regulations (2005) : Progress in the implementation of the five-year global strategic plan to improve public health preparedness and response (2018-2023), WHO, 2019. Notwithstanding, attention should be drawn to the observations made in 2017 by Andrew LAKOFF, in the essentially theoretical analysis he developed in his Unprepared. Global Emergency in a Time of Emergency, University of California Press, 2017; a work where two distinct models of emergency response are envisaged and outlined: one based on risk calculation and a precautionary imperative and the other based on the idea of preparedness or potential preparation (preparedness). In addition to the allusions made in the application for the current project, see, especially for terminological explanations, Bruce JENNINGS / John D. ARRAS / Drue H. BARRETT / Barbara A. ELLIS (Eds.), Emergency Ethics. Public Health Preparedness and Response, Oxford University Press, Oxford, 2016; Chloe SELLWOOD / Andy WAPLING (Eds.), Health Emergency Preparedness and Response, Cabi, Wallingford, Boston, 2016; Rebecca KATZ / James BANASKI (Eds.), Essentials of Public Health Preparedness and Emergency Management, 2nd Edition, Jones \& Bartlett, Wall Street, 2019.

38 Walter ScheIDeL, The Great Leveler: Violence and the History of Inequality from the Stone Age to the Twenty-First Century, Princeton University Press, Princeton, 2017; Jared Diamond, Collapse: How Societies Choose to Fail or Survive, Penguin Books, London, 2005. 
sophical field and - even more so - in its peculiar political and social endings. Moreover, the long-lasting centrality it has secured in the legal world (and in moral discourse), threatens to cloud the renewed meaning (eminently prospective and positive, institutional and structural) ${ }^{39}$ recently achieved on those first domains.

Indeed, the asseveration of a responsibility for social justice, in general, and for health, in particular, relies on a radical rethinking of the MitSein and an appeal to the objective solidarity brought about by natural and technical interdependencies as well as cultural aspects of sociality; it breaks with the exclusive and reducing circumscription of the category to the medullary (and indispensable) notion of moral and individualistic

39 In addition to Hans Jonas and Karl Otto-Apel - outstanding precursors of this shift in (or to) responsibility (whose works were deeply echoed within the walls of portuguese constitutional law, thanks to João Loureiro) - we have in view the structural responsibility (for the social connection) conceived and proposed by Iris Marion Young or the positive institutional responsibility suggested by Yasha Monk, or even the scheme of responsibility for harm, based on negative duties, delineated by Thomas Pogge - v. Iris Marion YOUNG, Responsibility for Justice, Oxford University Press, Oxford, New York, 2011; Yasha MONK, The Age of Responsibility. Luck, Choice, and the Welfare State, Harvard University Press, Cambridge (Ma), London, 2017; Thomas POGGE, World Poverty and Human Rights: Cosmopolitan Responsibilities and Reforms, 2nd ed., Polity Press, Cambridge, 2008. Praising Young's contribution (put into dialogue with others - by Derek Parfit, Christopher Kutz, Judith Lichtemberg, Mary Gray, Melissa Lane or Barbara Fried), Vafa GHAZAVI, "Ethics at a distance”, in The Politics of Care. From Covid 19 to Black Lifes Matter, Review \& Verso Books, Boston, 2020; Kathryn SIKKINK, "Rights and responsibilities in the pandemic Coronavirus", Open Global Rights, 30 March 2020 (text also explicitly influenced by Max Weber's Verantwortungsethik). The severe difficulties posed by these transfigurations of responsibility don't go unnoticed, nor the differences that separate them from the traditional configuration of legal responsibility are ignored, especially on account of the strict delimitation (quoad modum and quoad substantiatiam) that the latter's intersubjective matrix ensures. However, it would now be dislocated to dive deeper into the remarkable efforts made in order to consolidate the potential detected and already released by this Oberbegriffs eidos-ousia of practical reason - see, in the expectation of further developments on later and more propitious occasion - Kurt BAYERTZ / Birgit BECK, "Soziale Verantwortung Zur Entwicklung des Begriffs im 19. und frühen 20. Jahrhundert”. Preprints and Working Papers of the Center for Advanced Study in Bioethics Münster, 81, Westfälische Wilhelms-Universitäts, Münster, 2015; exploring the numerous possible declensions of responsibility, Ludger HEIDBRINK / Claus LANGBEHN / Janina LOH (Hrsg.), Handbuch Verantwortung, Springer, Wiesbaden, 2017; Jan Henrik KLEMENT, Verantwortung. Funktion und Legitimation e Begriffs im Öffentlichen Recht, Mohr Siebeck, Tübingen, 2006; Joseph RAZ, From Normativity to Responsibility, Oxford University Press, Oxford, 2012. 
imputation, ultimately grounded on the reason and freedom of the transcendental subject, underlying the empirical and phenomenal self.

Such responsibility... also holds us responsible for an adequate constitutionality, (capable of honouring it) and for the right law (able to do it justice), thereby performing the task values and embodying the core convictions that animate it, throughout the institutions of a culture-environment favourable to the corresponding ethos and the micro, meso and macro responsiveness, that signals its permanent openness to otherness and strangeness. Thus, a chain of responsibilities ${ }^{40}$ becomes apparent, linking a complex set of goods, both factually and normatively or ontically and axiologically, in the practical dynamics of the respective realization.

In fact, social justice (even with a global ambition) - as a requirement for the structurally integrated realization of personal equality, through all the societal spheres engendered around the access to the main collective goods - is doubly correlated, as a factor and an effect, with the fair provision of health care and the promotion and protection of public health, thence considered as their constitutive or expressive dimensions ${ }^{41}$.There is no social justice without health, nor health without health care and fair public health policies, the same way these, and the former, also benefit from social justice and its demands and repercussions in other sectors.

The infrastructural responsibility for the creation, maintenance and increase of practical institutions of care and attention regains legitimacy,

40 Neil Levy, “Taking Responsibility for Responsibility", in Public Health Ethics, Volume 12, Number 2, 2019, pp. 103-113; John Coggon, "Legal, Moral and Political Determinants within the Social Determinants of Health: Approaching Transdisciplinary Challenges through Intradisciplinary Reflection", Public Health Ethics, Volume 13, Issue 1, 2020, pp. 41-47.

41 Karien Stronks/Brigit Toebes/Aart Hendriks/Umar Ikram/Sridhar VenkaTAPURAN, Social justice and human rights as a framework for addressing social determinants of health. Final report of the Task group on Equity, Equality and Human Rights. Review of social determinants of health and the health divide in the WHO European Region, WHO Copenhagen, 2016; Richard Wilkinson/Michael Marmot (Eds.) Social Determinantes of Health: The Solid Facts, $2^{\text {nd }}$ edition, WHO, Copenhagen, 2003. Sudhir Anand/Fabienne Peter/Amartya Sen (Eds.), Public Health, Ethics, and Equity, OUP, Oxford, 2004; CSDH, Closing the gap in a generation: health equity through action on the social determinants of health (Final Report of the Commission on Social Determinants of Health), World Health Organization, Geneva, 2008; Daniel S. GoldBerG, Public Health Ethics and the Social Determinantes of Health, Springer, Cham, 2017. 
in a spiral of inter-influential correlations, since they are trained for permanent attentiveness, service and responsiveness, both to immediate requests and to people's deep needs (as well as to the multiple levels of factual and normative expectations they nurture), in relation to any occurrences at a personal level or of a collective and even international magnitude ${ }^{42}$.

\section{Constitutionality}

In both a broader and a stricter sense - to which the wide range of constitutional studies and the notions of political morality (as well those of political jurisprudence, political law or constitutional culture and software) seem to refer us - the nomos of constitutionality is hereby surprised at the heart of a triple crossroads: (i) between national and international axis, (ii) normality and normativity; (iii) law, politics and social arenas.

In the first case, by way of an interconstitutionality built as an aspiration of inter and transculturality, based on subjectivities, practices, institutions, systems, and trans-state intentions; in the second, as a socio-cultural response to the classic problem of integration and to the risk of Zerfall, against the fatalism of the böckenfordian oracle and to the detriment of the normative-formal (kelsenian), decisionist and concrete order (schmittian) and scientific-spiritual (smendian) models; finally, in the guise of a meta-medial trans-structuring-a(c)tion or trans-institutionaliz-a(c)tion that integrates pluralism and societal differentiation, in a scalar molecularity (from regional or local to global level), around the chronotopic incorporation or carnal root of man and the statutory modules (and corresponding ecosystems) of their equal freedom of realization.

In that first instance, it bears in mind the pandemic phenomenon, and in the second it opens up to the provocations caused by the pandemic disruption of daily life and its normative framework ${ }^{43}$, in

42 Luís Meneses do VAle, "Responsividade nos sistemas públicos de saúde: o exemplo da OMS", in Estudos de Homenagem ao Professor Doutor Figueiredo Dias, Volume IV, Coimbra Editora, Coimbra, 2010, pp. 1049-1106.

43 Since the normative assimilation of social needs, combining empirical well-being with recognized values/goods, and individual happiness with a eudemonistic idea of fulfilment, demolishes the counterfactual resistance to the emergence of situations 
the third, resuming the previous ones, it outlines the specific normative-constitutional and multilevel integration in context of global societal differentiation (by over-structuring the social sectors, from within, on the grounds of rights and their supporting institutions $\left.{ }^{44}\right)$. The extent to which it waits and responds, resists and confronts the ingredients of the tragedy (Jack Balkin), from its central core, is what will matter, in the case of health.

\section{Constitutional responsibility for justice and public health}

Taking for granted the adduced evidence as to the virtuous circle that justice and health tend to engender (at least whenever mutually reinforced through correct and just regulatory and sanctioning mediations), the corresponding constitutional (legal and political) responsibility for its guarantee appears as justified, deserving our strong commitment and advocacy ${ }^{45}$.

In a broad interpretation of the constitutional blocs and the transnational networks to which the Portuguese-speaking countries belong, several international responsibilities stemming from the universal and regional, generic and sectoral systems of rights ${ }^{46}$ call for special attention,

of need, re-enacting - for the umpteenth time - one of the greatest problems of post-Kantian practical philosophy and contemporary legal and political theory and methodology. Procedural or conflictual solutions (discursive or systemically-functionally autopoietic) do not manage to overcome this difficulty in a totally convincing way; and even material jurisprudentialism has a hard time struggling with it in the macro or mesoscopic contexts, better intended by a political social normativity of teleological modeling of complex actions and institutions, namely, through the system of attributions and competences of public entities finalized to the satisfaction of collective interests.

44 Drawing our attention - with another depth, scope and environment - to the trans- or supra-state dimensions of the issues in question, Joâo LOUREIRO, "Goods, Males and (E) (E) states (In) constitutional: Sociality and Freedom (s): Notes on a Pandemic", in Revista Estudos Institucional, v. 6, n. 3, Sept. / Dec. 2020, pp. 787-832.

45 On public health law, v. for instance, Lawrence Gostin (Ed.), Public Health Law and Ethics. A Reader, University of California Press, Berkeley, Los Angeles, London, 2002 e John Coggon/Keith Syrett/A.M. Viens, Public Health Law: Ethics, Governance and Regulation, Routledge, London and New York, 2017.

46 See the articles from the International Convention on the Elimination of All Forms of Racial Discrimination (12th and 11 th , no.1) the Convention on the Rights of the Child (24th), the Convention on the Rights of Persons with Disabilities (25th), the European Social Charter (11th and 13th), the EU Charter of Fundamental Rights (35th); the Oviedo Convention (3th), the African Charter on Human and Peoples' Rights 
with emphasis on the obligations stipulated in the ICESCR ${ }^{47}$ and further developed by the doctrinal jurisprudence of the Social Rights Committee - whether in terms of their applicability, effectiveness, intensity, pace and scope, or through the material distinction between duties of respect, protection and fulfilment (facilitation, promotion and provision) and a thorough specification of the main requirements concerning the social determinants of well-being, public health and health systems [availability, (geographic, financial, cognitive and timely) accessibility and acceptability]. An important array of demands that the Optional Protocol has made more pregnant, and the High Commissioners and Special Rapporteurs, on their side, have densified and determined with enormous courage and straightforwardness in recent years.

Internally ${ }^{48}$, what juts out is the adoption of a developmentalist

(16th); the African Charter on Welfare of the Child (14th); the Additional Protocol to the American Convention on Human Rights in the Area of Economic, Social and Cultural Rights (Protocol of San Salvador) (10th), among others ...

47 See art. 12. ${ }^{\circ}$ and Luís Meneses do VALE, "Sobre o sentido jurídico do acesso aos bens sociais fundamentais: a 'jurisprudência doutrinal' da ONU em matéria de saúde", e-cadernos CES, 15, 2012: 70-97; already during the pandemic - Pedro A. Villarreal, "Can They Really do That? States' Obligations Under the International health regulations in Light of Covid 19" (Part I e II), in Barrie SANDER/Jason Rudall (eds.), COVID-19 and International Law, Opinio Juris Symposium, March 30, 2020; Tim Fish Hodgson \& Ian Seiderman "COVID-19 Responses and State Obligations Concerning the Right to Health", Part I and II, Ibidem.

48 See: Constitution of the Portuguese Republic (64th), Constitution of the Brazilian Republic (196 to 199, in addition to art. 6); Constitution of the Republic of Angola (77th, but also 21st); Constitution of the Mozambican Republic (89 and 116). In turn, according to Article 123 of the Basic Law of the Macao Special Administrative Region, the Regional Government defines, on its own, the policy regarding the promotion of medical and health services and the development of Chinese and Western medicine and pharmacology. Social associations and individuals may, under the law, provide medical and health services of any kind. The Public Health Services of the SAR are dependent on the Secretariat for Social Affairs and Culture and are concerned both with the provision of differentiated and primary health care, as well as with the implementation of the actions necessary for the prevention of disease and the promotion of health (including surveillance epidemiology, health education, food hygiene, control of environmental hygiene vectors, occupational health and community health surveillance). Finally, it should be said that the actions of the authorities, during the pandemic, were governed, in this field, by the provisions contained in Law No. 2/2004 (law for the prevention, control and treatment of infectious diseases), drawn up and approved following the SARS epidemic in the early years of the current millennium. As for the constitution of China, among the General Principles is stipulated, in art. 21, ia, that the State, in order to protect people's health, must develop medical and health care, as well as modern and traditional 
paradigm, that relates social rights to public policies ${ }^{49}$, somehow along the lines of the so called common transformational constitutionalism, theorized by A. Von Bogdandy about From Latin America. Characteristics that some tend to deride, namely a certain romanticism and aspirational idealism - regarded, in the global north, as needless legal complication, utopian ingenuity or pure symbolic compensation (although shared with other Mediterranean countries) - make an important presence in these constitutions, inspiring their fundamental and structuring principles, the tasks of the State, the guarantee of the various sectors of production, the political subordination of the economy, the concern for interaction and social cohesion, and of course, the umbilical relationship established between social rights and their institutional guarantees of achievement, through democratically socializing infrastructures such as those beveridgian health systems.

The distance between norm and reality, text and action, performance and impact, perception, appreciation and public satisfaction varies significantly between Portugal, Brazil and the African countries ${ }^{50}$, without belittlement to the (intrinsic and consequential) value of the constitutional option for a democratic-social model of equalization (from all to all), aligned or tuned - whether in terms of health care access and financing, or in relation to these and other determinants of collective health, through well-being - with the millennium development goals, the ecological or environmental-social revolution regarding the determinants of health, the best standards of practice, the agendas for universalization, new public and common services, integrated systems, global health, equality-oriented policies, etc.

medicine, encourage and support the management of various medical and health infrastructures by collective rural economic organizations, public companies, public institutions and neighbourhood organizations, and to promote public health activities. And in art. 45, $\$ 1$, it is added that citizens of the republic must have the right to material assistance from the State and Society when they are elderly, sick or lose the ability to work. The State must, therefore, develop social security, social assistance and the medical and health services necessary for citizens to enjoy this right.

49 In Portugal and Angola along the various numbers of one and the same article (although the affirmation of a right is clear only in the first case).

50 Leaving aside, for the moment, the extreme case of Macau. Consider, as an example - indeed emblematic of the two cultures in question - the contrast between the scarce use of the judicial system, patent in Angola, and the accentuated judicialization registered in Brazil. 
In short, the preparation and responsiveness to health emergencies will stand out and increase in a society: (i) solidary, egalitarian and cohesive, where social peace and the possibilities of realization are works of justice (which consolidates interpersonal and institutional trust, contributing to individual and collective resilience); (ii) with public health policies transversal to the various social sectors and a fair public health system (both legitimate and effective); (iii) endowed with the capacity to act in an integrated manner, with the support and confidence of citizens, combining global public policies with sectoral ones, reflecting health in all of them and combining the various response systems.

\section{Under the Sign of Ananké: bealth needs}

\section{Overview ${ }^{51}$}

Whoever does not settle for the formalist escapism of an ideal normativism and refuses to yield to the pre-juridical sovereignty of a more or less theologized power, or surrender to the normatization of a purely contingent facticity - bringing, instead, the constitutive tension between axiological-normative demands of ideal validity and practical-material performative instantiations of its efficacy or effectiveness, into the culturally intelligible and experienced normativity - is faced, with regard to the law or state of need, emergency or exception, in an

51 As a locus classicus on the subject, on the $20^{\text {th }}$ century, please refer to the works of Carl Schmitt, especially from the 20s, namely, from the beginning of the 20s, Die Diktatur. Von den Anfängen des modernen Souveränitätsgedankens bis zum proletarischen Klassenkampf, 1921 e Idem, Politische Theologie. Vier Kapitel zur Lehre von der Souveränität, 1922. An easily understandable overview is available at Elliot BuLMER, Emergency Powers, International IDEA Constitution-Building Primer 18, IDEA, Stockholm, 2018. On a predominantly sociological perspective, cf. Matthias LEmke, "What does state of exception mean? A definitional and analytical approach", Zeitschrift für Politikwissenschaft, 28, 2018, pp. 373-383; Idem (Hrsg.), Ausnahmezustand. Theoriegeschichte-Anwendungen - Perspektiven, Springer, Wiesbaden, 2017. As a testimony to the variety of opinions on the subject, see the most recent collections: Gary GarstLe \& Joel Isaac (Eds.), States of Exception in American History, University of Chicago Press, Chicago, 2020; Cosmin Cercel, Gian Giacomo Fusco, Simon Lavis (Eds.), States of Exception: Law, History, Theory, London: Routledge, 2020; Richard Albert/Yaniv Roznai (Eds.), Constitutionalism under Extreme Conditions: Law, Emergency, Exception, Springer, 2020. 
extreme situation, suspended on the Radbruchian bridge between being and value, streaked between the lines of the Schranken and Grenzen of law, and forced to problematize these complex folds of human existence, knowledge and evaluation, which we would rationally like to deem medially-dialectically productive and superiorly synthesizing. As announced, the problem becomes even more sensitive if a jurisprudentialist perspective, which overcomes this difficulty through a finalizing decision at the end of a spiral of correspondences (all mutually tuned, between both the system and the legal controversy and the intentional problematicity of the norm and the problematic of the case ${ }^{52}$ ) gives way to a critically reconstitutive relationship between normativity and social reality - like the one implied in the domain of constitutionality (according to its intentional conscience of the correspondent phenomenon).

The abovementioned figure dates back to the beginnings of legal-political reflection, namely in the context of the Roman republic (where the dictator, appointed by the superior magistrates, was temporarily invested with the powers and symbols of Imperium), having been rethought by Machiavelli in the transition to modern age, or by Locke (theorizing the prerogative power) and then by Rousseau and Harrington, at the dawn of contemporaneity. Ultimately, this flow led to the explosive drama nurtured by the cultural, political, economic and social conditions in which the German Republic of Weimar was immersed. Owing to the contribution of (above all) Giorgio Agamben, the theme was somewhat reinvented by the continental philosophy of the late 20th and early 21 st centuries (inspired by Foucault's archeology and Walter Benjamin's theory of violence ${ }^{53}$ ),

52 Here, the negotiation between fact and law is resolved through a progressive concentration in the normative programme and the material scope of the norm (Müller), or the confluence of the pre-comprehensive decision of a case with the legally set out normative hypothesis (Esser), or even the hypothetically constructed norms to solve the case with the legally inscribed rules (Kriele).

53 Giorgio Agamben, Stato di eccezioni, Homo sacer, II, I, Bollati Boringhieri, Torino, 2003. See, also, the monumental edition of the series dedicated to the homo sacer: Homo sacer (1995-2015). Ediz. Integrale, Quodlibet, Macerata, 2018; possibly less convincing are the last considerations by the author, especially the polemic set of thoughts published on his editor's site and which were compiled in: Idem, $A$ che punto siamo? L'epidemia come politica, Quodlibet, Macerata, 2020. 
whereas the USA's ${ }^{54}$ constitutional theory would also revisit it, with great diligence, in the aftermath of the $9 / 11$ attacks and against the subsequent international neo-belligerent and homeland security paradigm, soon established in America - and progressively, extended to all over the world. Subsequently, the economic and financial crisis generated yet another penultimate wave of reconsiderations, which extended and stretched its borders and the significant potential for the domains of the action against the normalization of the forms of oppression and patriarchal, neocolonial and economic-social control, which have a supranational scope $e^{55}$.

\section{The Legal Framework}

\subsection{THEORY}

The constitutionally relevant situations of abnormality lend themselves to diverse possibilities of analysis, allowing for the organization of very heterogeneous typologies, according to the chosen criteria or along different axes of systematization: times, subjects, powers, measures, effects, objects, etc. Thus, it is possible to speak of monist and dualist models and modalities of authorization or

54 Cf. Bruce Ackerman, “The Emergency Constitution”, The Yale Law Journal, Vol. 113, 2004, pp. 1029-1091: and the discussion sparked by the Yale Professor v.g., David Cole, The Priority of Morality. The Emergency Constitutions Blind Spot", The Yale Law Journal, 113, 2004, 1753 e ss; Kim Lane Scheppele, "Law in a Time of Emergency: States of Exception and the Temptations of 9/11", Journal of Constitutional Law, Vol. 6, 5, May, 2004, pp. 1001-1083; Laurence H. Tribe and Patrick O. GuDRIDGE, "The Anti-Emergency Constitution”, Yale Law Journal, 113, 2004, pp. 1801 e ss; Martha Minow, "The Constitution as Black Box During National Emergencies: Comment on Bruce Ackerman's Before the Next Attack: Preserving Civil Liberties in an Age of Terrorism", Fordham Law Review, 75, pp. 593 (2006).

55 See, for example, Lorenzo Cotula, "The state of exception and the law of the global economy: a conceptual and empirico-legal inquiry", Transnational Legal Theory, 8:4, 2017, pp. 424-454; José Atiles-Osoria, and D. Whyte, "State of Exception, Law and Economy: A socio-legal approach to the economy of exception in an era of crisis", in Oñati Socio-legal Series, 8 (6), 2018, pp. 808-818. Environmental disasters - with more or less broad impact (such as hurricane Katrina) and the epidemics that mainly emerged in the orient and Africa, added to these. 
ratification ${ }^{56}$, involving implicit powers ${ }^{57}$ or explicit enabling clauses $^{58}$, contemplating strictly bound, discretionary, free and even irresponsible, ordinary or extra-ordinary, legal or non-legal, constitutional or legislative, political or administrative, suspensive or restrictive regimes. Darning some of the most advanced and best achieved taxonomies, it may be possible to elaborate further on the gap between models of legal provision, accommodation (or of internalization and normative domestication of a clearly differentiated facticity), irrelevance and extralegal reaction ${ }^{59}$.

\subsection{DogMATIC}

a) National: In view of the subject which will be addressed on the next chapter of this White Book, there is no need for further considerations on the topic at this point: we shall only underline that the Portuguese constitutional corpus allows for a distinction between an external (of war or military emergency) and internal state of need. Flanked by situations of serious threat or disturbance to the democratic constitutional order, - under the latter hypothesis - the occurrence of pandemics, together with other natural or human disasters and serious accidents should be interpreted, in a normative manner, as an example of public calamitiy ${ }^{60}$. Once

56 As are the British Indemnity Bills, for example.

57 As it happens, to a large extent, in the USA.

58 See the notorious article 48 of the German Weimar Constitution and article 16 of the 1958's French Constitution.

59 Oren Gross/Fionnuala Ní Aolaín, Law in Times of Crisis. Emergency Powers in Theory and Practice, CUP, Cambridge, 2006; David Dyzenhaus, The Constitution of Law. Legality in Time of Emergency, Cambridge University Press, Cambridge, New York et al, 2006; John Ferejohn/Pasquale Pasquino, "The law of the exception: A typology of emergency powers", International Journal of Constitutional Law, Volume 2, Issue 2, April 2004, pp. 210-239; based on these authors, Miguel Nogueira de BrITO, "Modelos de Emergência no Direito Constitucional", e-Pública, Volume 7, N.o 1, Abril, 2020, pp. 6-26; cfr. Jorge Bacelar Gouveia, O Estado de Excepção no Direito Constitucional: Entre a Eficiência e a Normatividade das Estruturas de Defesa Extraordinária da Constituiçâo, vol. II, Almedina, Coimbra, 1998; Idem, Estado de Exceção no Direito Constitucional: Uma Perspetiva do Constitucionalismo Democrático - Teoria Geral e Direito Português, Almedina, Coimbra, 2020.

60 J.J. Gomes Canotilno, Direito Constitucional e Teoria da Constituição, 7. ${ }^{a}$ edição, Almedina, Coimbra, pp. 1083 and ff. 
the respective material preconditions are verified, the Constitution provides for the possibility of instituting a legal regime or discipline of the state of need, which essentially consists of a collective suspension of rights that the President can declare whilst opting between the state of siege or emergency (separated by tenuous lines...), depending on the severity of the case at hand - by decree presented to the AR (Assembleia da Repúbli$c a$, which corresponds to the Parliament), after consulting the government, and subject to a governmental referendum if, and when, the declaration has been previously authorized (or later confirmed) by the $\mathrm{AR}^{61}$. In addition to these formal, procedural and organic limits, addressing the substance of this institute (i) certain constitutional rights and principles are excluded from the potential scope of suspension ${ }^{62}$, (ii) the specification of the affected rights is required, (iii) a limited time frame for its effects to be produced is defined, and (iv) special caution is requested in observing the principles of prohibition of excess, as well as, of course, equality and non-discrimination. The main legal regime continues to act as a parameter for the declaration of state of siege or emergency and for the measures adopted in its execution, guaranteeing the possibility of judicial review, beyond parliamentary political control.

b) International: regarding the derogation of rights, it is also worth highlighting, albeit briefly, the protection granted by the OHCHR (art. 4), supported by the Syracusa Convention and, specifically, General Comment no. 29, as well as the International Health Regulations, maxime in its article 43. So widely ignored during the national and international management of the pandemic, they led Lawrence Gostin and other experts, as early as February $2020^{63}$, to call for international compliance with this normative complex. With the intention of elucidation collimated without a doubt to a greater

61 See articles 19, 134/1/d), 138, 140/1, 161/l) and 197/1/f) of the CRP.

62 In harmony with what is set out in article 4 of the International Covenant on Civil and Political Rights (OHCHR), article 27 of the American Convention on Human Rights or in article 15 of the European Convention on Human Rights (ECHR).

63 "Do not violate the International Health Regulations during the COVID-19 outbreak", The Lancet, 20 February, 2020 
dissemination, transmission and inculcation in the collective conscience and to the modeling of the agency of the responsible public entities, beginning by the States, as well as by the populations, a consensus was reached and established not long ago by the the Stellenbosch Consensus on Legal National Responses to Public Health Risks ${ }^{64}$. Although it is not possible to analyze its content in this short space, it is an instrument which invites a devoted study of the legal nexus with which, in the future, state responsibilities in matters of health in general and public health in particular must be entangled, in addition to other requirements, of global solidarity, international trade and protection of rights of which real well-being and personal fulfillment (essential to the mutual support of individual and collective health) are dependent.

\section{The National Narrative: from Pathos to Logos}

If history only records accidents seismographically, forgetting, among the harsh peaks of change, the flat valleys of lukewarm happiness, we should not be surprised by the fascination and attraction of its privileged writers to epidemic phenomena. The metaphorical propensity and allegorical helpfulness will not weigh less in this calculation/ underbudgeted/lesser amount, to which are added the dramaturgical form they tend to assume (Charles Rosenberg) and the social choreography they exhibit as they unfold in time and space ${ }^{65}$.

In Lusophone countries history is told at various speeds and rhythms, impossible to track at length, therefore we shall only describe (and in a non-detailed way) the intricacies of the Portuguese novel. It contains two episodes of lockdown that began in March 2020 and January 2021, interspersed with a period where lockdown was lifted, from May to September; it includes three states of emergency decreed in March and November (2020,) and January (2021), which were followed by successive renewals each time; and it extends, as in a Leitmotiv, by a lasting and rarely relieved administrative management of

64 Available at: International Organizations Law Review, 2020, 1-68.

65 Jeremy A. Greene \& Dóra Vargha, "How Epidemics End”, June 30, 2020, in Thinking in a Pandemic: The Crisis of Science and Policy in the Age of COVID-19, op. cit. 
the calamity, throughout almost all of this period. The cast includes first-class institutional actors, such as the PR, the AR, the Government, the Autonomous Regions, the Municipal Councils, the Health Administration, the Courts and the Ombudswoman, but also the citizens and many of their civic and professional associations (orders, unions, leagues, employers' confederations, etc.), in addition to the media and social networks - the face to the world -, a plethora of specialists (promoted from the rear to the antenna) and social movements, more or less inorganic. Among many other topics and, most of all, in the midst of an immense list of non-trivial details, three major legal issues would perhaps deserve a more extended look: the opportunity and content of the declaration of state of emergency and the respective execution by the government; administration in a state of calamity; the holding of elections during the pandemic, all in the meantime leading to proposals of iure condendo and lege ferenda, regarding the constitution and current legislation.

Essentially, the deeds can be narrated as follows: in view of the international scenario and despite the absence of cases in Portugal, on March $2^{\text {nd }}$, the Government began to adopt restrictive measures, set out in the civil protection law, the Framework Law on Health, and the health surveillance law. Strong social pressure, especially by health professionals, led the PR to declare the first state of emergency, even though, in principle, it was possible for the executive to restrict the affected rights, which are subject, according to Reis Novais, to a "reserva imanente de ponderação" (theory which proposes that a right is inherently "born" with limits) ${ }^{66}$. In addition, the President's decree did not suspend the right to personal freedom, which was instead primarily affected by the core of government intervention (and which

66 Jorge Reis Novais, "Estado de Emergência - Quatro notas jurídico-constitucionais sobre o Decreto Presidencial", Observatório Almedina, 19 de Março de 2020; Idem, "Direitos Fundamentais e inconstitucionalidade em situação de crise - a propósito da epidemia COVID 19", in e-Pública, Vol. 7., N.o 1 Abril, 2020, pp. 78 117; Pedro Costa Gonçalves, "Abdicação parlamentar na emergência e continuação da abdicação na calamidade", Observatório Almedina, 21 de Maio de 2020. Similar proposals were presented internationally, by authors such as Martin Scheinin. In Germany, inversely, the lack of constitutional measures that could expressly be invoked was resented. For a comparative analysis of the response, see: Joelle Grogan, "Power and the COVID-19 Pandemic - Introduction \& List of Country Reports", VerfassungsBlog, 2021/2/22. 
constituted the main argument for resorting to its suspension, if we are not mistaken), who also delegated powers to delimit the suspended rights, a measure with questionable constitutional conformity. It could hardly be said, in any case, that the Government's measures were a mere execution of the presidential decree: they had, in fact, a constitutive role, in material terms, in the restriction of rights, which is why they should have assumed the legal format, and not just a regulatory nature, like it ended up happening. In any case, after two renovations, without significant changes in these problematic points, the state of emergency expired on May $2^{\text {nd }}$, and gave way to an administrative state of calamity (in turn renewed until June $28^{\text {th }}$ ), framed by the above mentioned legislation, confident in the citizens' civic conscience, as the restrictions were gradually being lifted. However, the summer sun did not last long and in September the infection rates rose again, at the same time as new strategies (such as compulsory use of masks and the evaluating the possibility of implementing a mobile digital application to track contacts) were entered on the agenda. Although the first measure was definitively incorporated on the agenda with no hesitation, the second entered the agenda hesitantly, and ended up completely failed. The worsening of the situation resulted in the declaration of another state of emergency on November $6^{\text {th }}$ and in the implementation of more severe constraints during the month of December (night curfews during the week, and from $1 \mathrm{pm}$, at the weekends). The failure of restraint during the festive period (perhaps due to the regulatory complexity of the measures), combined with the early appearance of new virus strains in the country, resulted in the blackest period of the pandemic, in January, inducing the implementation of another lockdown, from the middle of the month, in the face of the alarming numbers of deaths and infections, the congestion of hospitals and the imminent rupture of the system. Measures were not adopted to guarantee that the presidential election was conducted with more safety and it was held on the scheduled date. The arguments put forward in favor of a possible postponement (notwithstanding the constitutional deadlines admitting a relative delay) were not convincing, and the concern over maintaining a healthy democratic regularity outweighs them. From this experience, however, it was learned that there is need to calmly consider a reform of the system, although without embarking on an occasional and polemic electronic alternative, which lacks research and debate; and this because 
the logistical lack of preparation, particularly with regard to early voting, was very much noticeable ${ }^{67}$.

In addition to the aspects emphasized above, and many other points of uncontroversial interest, there were other subjects of permanent discussion, including: (i) the lack of professionals (and the ways of supplying them, with immediate importation, expansion of the network of institutions that provide training, relaxing corporate constraints, etc.); (ii) the authorities' communication protocols; (iii) testing and, later, vaccination programs and plans; (iv) remote attendance and monitoring systems (by telephone); (v) the strategy of articulation between economic sectors included in the broad concept of health care system; (vi) the possible definition of rules for prioritizing or rationing access to care; (vii) the financial support provided and the economic and social support solutions for business expenses with personnel; or (viii) privacy hindered by rapid telematization and the imminence of recourse to digital patient tracking systems. These can be understood as tips to strengthen the response capacity of the population as a whole, of cities, regions and countries, of the various economic sectors and above all, of the national health service to situations of emergency and adversity.

\section{Elements for a Paideia}

From the impact caused by the pandemic, in particular, on our self-understanding as inhabitants of one Earth and members of a common Humanity, we will certainly draw conclusions - hopefully interconnected, and profound - regarding human values and rights, constitutions and the law, the social structures that guarantee and instantiate them and the subjects, praxis and institutions who carry this structuring responsibility.

We present a handful of pointers, somewhat unstructured, since they are systematically reflected in the recommendations advanced by the team responsible for the project, which are organized later on in this Book.

67 Early voting was not available to citizens who were under surveillance (to detect a possible infection) after January $14^{\text {th }}$. Also, queues to vote were long and citizens waited for significant lengths of time to vote, not always following the recommended sanitary measures. 
- With regard to health, per se: (i) telemedicine and the rapidly growing electronic health, call for thoughtful planning, which does not undermine the importance of human contact; (ii) public health must be significantly revalued in all its aspects, taking into account the impact pyramid and circles of determinants of health; (iii) the health care response lacks integration at various levels (since hospitals remain essential) and requires the involvement from the community, through which citizens participate responsibly in its organization and functioning; (iv) after years of disarray the agendas of communization, integration, universality, intersectionality and transversality gain particular importance.

- From a scientific-cultural and communicative-informational point of view, (i) science must be collaborative and prestigious, subject to financial and social support and recognition; (ii) access to the internet emerged as a fundamental right and its provision cannot be left to operators controlled solely by weak regulators (focused on guaranteeing substantial results through economic competition); (iii) schools and health establishments are primary investment areas, starting from the quality of common spaces, which should be open to society and are essential to guarantee the maintenance of in-person social relationships in times of crisis; (iv) the creative industry and cultural habits and media play an irreplaceable role (including in the field of mental and family health) in the face of social unrest and the existential void; (vii) the media carry increased responsibilities during crises such as the one we live in, whether in terms of informing the public, or as guarantors of criticism and plurality of opinions, or even in the exercise of primary educational and pedagogical functions.

- Regarding the economy, in general, (i) as in many other aspects, the crisis does not affect everyone equally; (ii) the advantage of a coexistence between the economic sectors is evident, as their differences stand out and can result in a more fruitful relationship; (iii) planning is crucial; (iv) international cooperation calls for urgent improvements; (v) logistics chains cannot escape the scrutiny and control of the authorities; (vi) development is not, in fact, to be confused with growth;

- In the urban and housing dimensions, (i) human corporeality and the consequent need for common luxury became evident, as 
important investment sectors on what belongs to everyone, as a place of quality, safety, hygiene, well-being and sociability (therefore resistant privatization and complete idiotization of our existence); (ii) in parallel, however, the quality of housing remains a major problem, as well as (iii) the articulation of one and the other, in urban models designed for man, which guarantee an interface between private and public life, and private and community living.

From somewhere comes to us the parallel between pandemic cities and the surreal landscapes of De Chirico, empty of men. Fundamental nodes of a networked constitutionalism in a global world of cities, in an unstoppable expansion, they rediscover themselves, however, as the ideal place of the reinvented (e) utopia - classic and medieval, modern and contemporary - of man's realization and flourishing. We must, therefore, engage ourselves to the public imagination that transforms them, committed to honoring the hopes we have been dreaming in these times of isolated dispersion for them and us. If so (and we are worthy of such), as someone has also suggested, evoking Neruda's noble speech, sooner rather than later the day will come when, at last,

"A l'aurore, armés d'une ardente patience, nous entrerons aux splendides Villes."

(Rimbaud) 